\title{
EGFR genomic alterations in cancer: prognostic and predictive values
}

\section{Giuseppe Bronte $^{1}$, Marianna Terrasi ${ }^{1}$, Sergio Rizzo ${ }^{1}$, Nicola Sivestris ${ }^{2}$, Corrado Ficorella ${ }^{3}$, Massimo Cajozzo ${ }^{4}$, Francesca} Di Gaudio $^{5}$, Gaspare Gulotta ${ }^{6}$, Sergio Siragusa ${ }^{7}$, Nicola Gebbia ${ }^{1}$, Antonio Russo ${ }^{1}$

${ }^{I}$ Department of Surgical and Oncological Sciences, Section of Medical Oncology, University of Palermo, Palermo, ${ }^{2}$ Medical and Experimental Oncology Unit, Cancer Institute, Giovanni Paolo II, Bari, Italy, ${ }^{3}$ Department of Experimental Medicine, University of L'Aquila, L'Aquila, Italy, ${ }^{4}$ Department of Surgical and Oncological Sciences, Section of General and Thoracic Surgery, University of Palermo, Palermo, Italy, ${ }^{5}$ Department of Medical Biotechnologies and Legal Medicine, University of Palermo, Palermo, Italy, ${ }^{6}$ Department of General Surgery, Urgency, and Organ Transplantation, University of Palermo, Italy, ${ }^{7}$ Chair and Unit of Hematology transplant, Azienda Ospedaliera Universitaria Policlinico P. Giaccone, Palermo, Italy

\section{TABLE OF CONTENTS}

1. Abstract

2. Introduction

3. Egfr Protein Expression

4. Egfr Mutations In The Tyrosine Kinase Domain

5. Egfr Mutations In The Extracellular Domain

6. Egfr Gene Copy Number

7. Perspective

8. Acknowledgement

9. References

\section{ABSTRACT}

The role of EGFR in cancer development and progression has been recognized for long time in a variety of human malignancies including lung, head and neck, colon, breast, ovary and glioma. Recently its role as a target of antineoplastic agents has also been identified and a variety of EGFR-targeted drugs is already being used in a clinical setting and others are at present under investigation. Many data involving EGFR protein expression are now available for the choice of anti-EGFR monoclonal antibodies in colorectal cancer and with regard to EGFR gene mutations for the choice of tyrosine kinase inhibitors in lung cancer. Other EGFR-related molecular factors, including the EGFR gene copy number, are currently under investigation. This review summarizes both preclinical and clinical available data regarding EGFR genomic alterations as prognostic and predictive factors.

\section{INTRODUCTION}

The epidermal growth factor receptor (EGFR) and members of its family are important targets for cancer treatment due to their ability to stimulate cell proliferation, survival and migration in normal and cancerous cells (1). The EGFR gene is located on chromosome 7p12-13 and encodes a tyrosine kinase receptor composed of four functional domains: an extra-cellular cysteine-rich ligandbinding domain, which can be further divided into four additional sub-domains (EGFR-I, EGFR-II, EGFR-III, EGFR-IV); a trans-membrane domain; an intracellular tyrosine kinase (TK) domain and a C-terminal domain which functions as a regulator (2). The binding of the epidermal growth factor (EGF) or other ligands, such as betacellulin, epiregulin, TGF- $\alpha$, amphiregulin, and heparinbinding EGF-like growth factor (HB-EGF), to the extracellular domain, induces homodimerization of two 
Table 1. The most important studies about correlation of EGFR protein expression and efficacy of anti-EGFR drugs

\begin{tabular}{|c|c|c|c|c|c|}
\hline Study & Phase & Tumor & $\begin{array}{l}\text { No. of } \\
\text { patients }\end{array}$ & Treatment & Results \\
\hline $\begin{array}{l}\text { Saltz LB, et al. } \\
\text { J Clin Oncol } 2004 \text { (8) }\end{array}$ & II & CRC & 57 & Cetuximab & $\begin{array}{l}\text { No correlation of response rate with EGFR expression } \\
\text { levels }\end{array}$ \\
\hline $\begin{array}{l}\text { Cunningham D, et al. } \\
\text { N Engl J Med } 2004(10)\end{array}$ & $\begin{array}{l}\text { II } \\
\text { (randomized) }\end{array}$ & $\mathrm{CRC}$ & 474 & $\begin{array}{l}\text { Cetuximab + irinotecan } \\
\text { Vs Cetuximab alone }\end{array}$ & $\begin{array}{l}\text { No correlation of response rate with EGFR expression } \\
\text { levels }\end{array}$ \\
\hline $\begin{array}{l}\text { Lenz HJ, et al. } \\
J \text { Clin Oncol } 2006(9)\end{array}$ & II & $\mathrm{CRC}$ & 346 & Cetuximab & $\begin{array}{l}\text { No correlation of response rate with EGFR expression } \\
\text { levels }\end{array}$ \\
\hline $\begin{array}{l}\text { Berlin J, et al. } \\
\text { Clin Colorectal Cancer } \\
2007 \text { (12) }\end{array}$ & II & $\mathrm{CRC}$ & 43 & $\begin{array}{l}\text { Panitumumab + IFL or } \\
\text { FOLFIRI }\end{array}$ & $\begin{array}{l}\text { No correlation of response rate with EGFR expression } \\
\text { levels }\end{array}$ \\
\hline $\begin{array}{l}\text { Hecht JR, et al. } \\
\text { Clin Cancer Res } 2010 \\
\text { (13) }\end{array}$ & II & $\mathrm{CRC}$ & 388 & Panitumumab & $\begin{array}{l}\text { Clinical responses found also in patients with negative } \\
\text { EGFR }\end{array}$ \\
\hline $\begin{array}{l}\text { Douillard JY, et al. } \\
\text { J Clin Oncol } 2010 \text { (17) }\end{array}$ & III & NSCLC & 380 & Gefitinib vs docetaxel & No predictive role of EGFR protein expression \\
\hline $\begin{array}{l}\text { Herbst RS, et al. } \\
\text { J Clin Oncol } 2005 \text { (20) }\end{array}$ & III & NSCLC & 1079 & Erlotinib vs placebo & $\begin{array}{l}\text { No correlation between EGFR expression levels and } \\
\text { clinical outcomes }\end{array}$ \\
\hline $\begin{array}{l}\text { Tsao MS, et al. } \\
\text { N Engl J Med } 2005 \text { (27) }\end{array}$ & III & NSCLC & 325 & Erlotinib vs placebo & $\begin{array}{l}\text { Correlation of EGFR protein expression with an } \\
\text { objective response }\end{array}$ \\
\hline $\begin{array}{l}\text { Hirsch FR, et al. } \\
J \text { Clin Oncol } 2006 \text { (28) }\end{array}$ & III & NSCLC & 379 & Gefitinib vs placebo & $\begin{array}{l}\text { Correlation of EGFR protein expression with clinical } \\
\text { outcomes }\end{array}$ \\
\hline
\end{tabular}

EGFRs or heterodimerization of EGFR with other members of its family, particularly with HER2. In this way the tyrosine kinase domain becomes active, causing the autophosphorylation of C-terminal domain (3). The phosphorylated tyrosine residues are the binding sites for adapter proteins and this activates different pathways, including that of MAPK, PI3K and STAT3/5 (4). This explains how EGFR overexpression or aberrant activation induces proliferation, invasion and metastatization, all mechanisms associated with tumor phenotype.

Since EGFR is involved in a variety of human cancers, including those involving the lung, head and neck, colon, breast and ovary and also gliomas (5), and has been linked to poorer outcomes (6), EGFR inhibitors have improved the range of treatments for various solid tumors. Different clinical studies have been conducted with these agents alone or in combination with other anticancer drugs and it has been seen that their action depends not only on tumor type but also on other factors, such as EGFR gene alterations. In the light of the evidence which has emerged in recent years, the aim of this review is to find out whether EGFR protein expression, mutation status and gene copy number can be considered as predictive and prognostic biomarkers for the efficacy of EGFR target therapy, in particular with regard to anti-EGFR monoclonal antibodies and tyrosine kinase inhibitors (TKI).

\section{EGFR PROTEIN EXPRESSION}

EGFR expression and cancer prognosis have been investigated in several types of human cancers and although there are some conflicting results, patients with EGFR over-espression tend to have poor prognosis. The tissue expression of the EGFR protein is estimated between 60 and $85 \%$ in colorectal cancer (CRC). Its increased expression seems to be correlated with a higher stage, aggressiveness, presence of metastases and poorer prognosis. In the first clinical studies with anti-EGFR monoclonal antibodies, only patients affected by mCRC expressing EGFR protein were included. This limitation derived from the supposition that these agents could be effective only when their target is present in cancer cells. Subsequently retrospective analysis of these clinical trials suggested a less clear role of EGFR positivity for the prediction of the response to these monoclonal antibodies. In fact, patients with EGFR-negative mCRC also showed benefit from this treatment (7) (Table 1).

Three different clinical trials have evaluated the relationship between the response rates in patients treated with anti-EGFR monoclonal antibodies and the EGFR tissue expression levels tested by immunohistochemistry (IHC) and no correlation was found in any of these studies (8-10) (Figure 1).

Both objective response and stable disease rates in EGFR-negative cases appeared similar to EGFR-positive patients $(9,11)$ and these results were confirmed in mCRC patients treated with panitumumab $(12,13)$. Several studies have shown that there is no significant correlation between EGFR expression by IHC and efficacy of TKIs even in NSCLC patients (14-26). Two clinical trials comparing erlotinib and gefitinib with a placebo for non-small-cell lung cancer both demonstrated a survival benefit $(26,27)$, while phase II studies and three other phase III randomized studies $(16,19,28)$ did not find a significant relationship (Table 1). Thus, EGFR protein expression cannot be considered as a useful biomarker of activity for anti-EGFR TKIs. Some authors have attempted to explain these findings $(7,29)$. They found possible reasons in the biological and technical problems related to the limitations and nonquantitative nature of conventional IHC.

The following limits of IHC have been recognized for some considerable time:

- malignant cells of a tumor are heterogeneous, so the EGFR expression is variable within a neoplastic mass. 


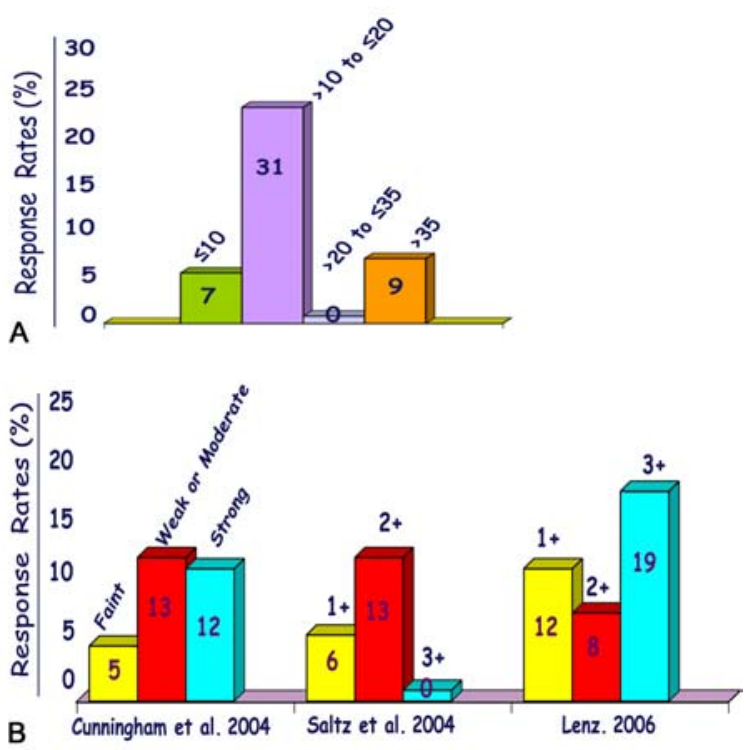

Figure 1. Differences of response rates to Cetuximab according to the EGFR staining intensity (A) and the percentage of the EGFR expressing cells (B).

EGFR protein includes both high and low affinity binding domains. Only the high affinity domains, which are usually poorly expressed, exert an effective biological function. The authors supposed that IHC could not be sensitive enough to recognize the high affinity binding sites. IHC allows the overall evaluation of EGFR protein, but is not able to distinguish the various receptor types with different biological activity

- the IHC-applying laboratories use different methods regarding the management of the specimens, and involving the tests and data reporting.

- $\quad$ the primitive site of the tumor and its metastases seem to express the EGFR protein differently.

At present, an effective scoring system and clear guidelines involving the standardization of EGFR protein evaluation by IHC are required.

\section{EGFR MUTATIONS IN THE TYROSINE KINASE DOMAIN}

EGFR mutations in the tyrosine kinase domain have been classified "as activating mutations" because they are all responsible for a ligand-independent activation of TK activity. Such mutations have been found in lung adenocarcinoma and more frequently among East Asian female patients with this type of cancer but without a smoking history $(30,31)$. The genomic region most affected by TK domain mutations is between exons 18 and 21 and the majority of EGFR mutations are deletions in exon 19 (over 20 variant types) and point mutation which substitutes an arginine with a leucine at codon 858 (L858R) in exon 21 (30). As minor EGFR mutations, there have also been reports of mutations at codon 719 (exon 18), 765 and
783 (exon 20) and in-frame insertion mutations in exon 20. Activating mutations have been found to confer sensitivity to the TKIs gefitinib and erlotinib (31-33) as the compromised ATP affinity of the EGFR mutants renders them susceptible to inhibition $(34,35)$. In fact, for patients harboring those mutations in the TK domain of EGFR, the response rate with erlotinib and gefitinib is approximately $70 \%(36,37)$. Several reports have suggested that patients with exon 19 deletions have a longer PSF and overall survival compare to those with the L858R mutation after treatment with erlotinib and gefitinib $(38,39)$. Furthermore, no significant differences in response rate, median PFS and survival between the two TKIs have been observed (40). The INTEREST study has shown gefitinib to be a valid treatment option for patients with pretreated advanced nonsmall-cell lung cancer, proving to be non-inferior in overall survival and similar in tumor response and progression-free survival to docetaxel (41).

The IPASS trial compared first-line gefitinib with carboplatin/paclitaxel in Asian patients with advanced NSCLC and with no history of substantial smoking. Patients harboring EGFR mutations had a significantly longer PFS with gefitinib (HR, 0.48; $P<0.001$ ), whereas those with wild-type $E G F R$ had a better PFS with chemotherapy (HR, 2.85; $\mathrm{P}<0.001)$ (42). Not all tumors having activating mutations are associated with greater response to treatment with gefitinib and erlotinib; their clinical efficacy is limited by the development of acquired drug resistance such as mutation of the substitution of threonine 790 with methionine (T790M), which has been detected in $50 \%$ of clinically resistant patients $(43,44)$ and has been associated with a short PFS (7.7 months in patients with the T790M mutation and 16.5 months in those without the mutation) (45). Nevertheless, the T790M mutant remains sensitive to irreversible inhibitors, such as EKB-569 and HKI-272 (43, 46, 47). In vitro studies have shown that EGFR T790M restores the affinity for ATP to the same levels of WT EGFR (48). In NIH 3T3 cells the T790M with the L858R mutant increases EGFR activity and enhances the transformed phenotype (49) and transgenic mice expressing T790M mutant develop lung adenocarcinomas (50), although with a longer latency than those harboring the L858R or combined L858R and T790M mutations $(51,52)$.

The T790M mutation has also been detected in a small fraction of tumor cells before drug treatment, supporting the idea that tumor cells harboring this mutation might be present from the beginning of the treatment with gefitinib or erlotinib and be enriched over time (52). Genetic heterogeneity of tumors is an issue to be considered when interpreting EGFR mutation data. In recent years, it has been suggested that, in order to detect a small fraction of mutant alleles among a large number of wild-type alleles in clinical samples, it is advisable to use a sensitive assay, such as SARMS technology, rather than direct DNA sequencing (53). Contrary to what was observed in non-small lung cancer, mutations in the catalytic domain of EGFR are rare in CRC, suggesting that gefitinib is unlikely to be effective in patients with these tumors (54-56). 


\section{EGFR MUTATIONS IN THE EXTRACELLULAR DOMAIN}

In the extracellular domain of EGFR, three different types of deletions have been found, defined as EGFR variant I, II and III (EGFR vI, EGFR vII and EGFR vIII). The most common of the three mutants found in human cancer is EGFRvIII, consisting of in-frame deletion from exons 2 through 7 (amino acids 6-273) in the extracellular domain, resulting in ligand-independent constitutive activation of EGFR (57). This mutation has not been observed in normal tissue (58) and is expressed in a number of cancers, including breast cancer, ovarian cancer, prostate cancer, and lung cancer (58) most notably glioblastoma (59-61), where it is reported to occur at a frequency of $20 \%-30 \%$ and in $50 \%-60 \%$ of tumors the amplification of wt EGFR is observed $(62,63)$.

In glioblastoma cell lines, EGFRvIII confers resistance to gefitinib with constitutive activation of EGFR and persistence of phospho-Akt (64)._In lung cancer, contrary to the other deletions and mutations of EGFR, EGFRvIII expression is relatively resistant to gefitinib and erlotinib and more sensitive to treatment with irreversible EGFR TKIs such as HKI-272 (65). In mCRC this variant is rare and does not play an important role (66).

\section{EGFR GENE COPY NUMBER}

Amplification or high polysomy of EGFR have been detected in a variety of solid malignant tumors, and have been associated with poor prognosis (67). In NSCLC, the gene copy number appears to be a promising biomarker for predicting a survival benefit with EGFR-TKI therapy in both second line, $(68)$ and third line clinical trials $(26,27)$ and is more predictive of patient survival after gefitinib treatment than EGFR mutations (69). However, the predictive value of $E G F R$ gene amplification for TKI sensitivity has proved to be lower in Japanese cohorts than in Western NSCLC cohorts. These findings suggest a possible difference mechanism of EGFR pathway activation in NSCLC between Asian and Caucasian populations $(70,71)$. A high EGFR copy number is frequently correlated with EGFR somatic mutations, (7277) although, since it is difficult to obtain sufficient amounts of tumor tissue for genetic analysis from patients with advanced NSCLC, the relationship between these two types of EGFR alterations has remained unclear. In CRC, discrepant results have emerged from recent studies. As emerged from two large studies, the percentage of CRC with increased $E G F R$ copy number is probably only $10 \%$ to $15 \%$ of tumors $(29,78)$ but despite the low incidence it seems to be an interesting predictor of response to antiEGFR $(55,79,80)$. Contrary to these authors, Lenz et al. (9) showed a positive relationship between increased $E G F R$ gene copy number (determined by quantitative PCR) and OS of patients, but not with PFS or response to cetuximab. Finally Khambata-Ford $\mathrm{S}$ et al, did not find any correlation between increased EGFR copy number and response to cetuximab (81). So we need further data to conclude about its applicability in clinical practice for decision making of anti-EGFR monoclonal antibodies.

\section{PERSPECTIVE}

The EGFR-related pathway is recognized as one of the main molecular mediators of tumor development and progression. When this pathway becomes abnormally activated, tumor cells acquire independence from mitogenic extracellular signals. Constitutive activation of the EGFR pathway induces prognostic worsening. For this reason, some researchers have developed new molecules to target both the extracellular and the intracellular domain of the EGFR. Since the cost of these agents is often higher than conventional chemotherapeutic drugs, research is continually underway in order to discover predictive factors leading to the clearer identification of potential responders.

At the present time, the anti-EGFR monoclonal antibodies, cetuximab and panitumumab, are frequently used in advanced colorectal cancer management. EGFR protein expression by IHC was initially considered a mandatory requirement to deliver these drugs but later some authors have highlighted the absence of relationship between EGFR expression and clinical response in these patients. To date others parameters are required for the selection of patients to be treated with these monoclonal antibodies. The EGFR gene copy number and mutations have not proved to have any role as predictive factors in this setting of patients. KRAS and BRAF mutation testing has now become fundamental to assess responsiveness in colorectal cancer patients.

Activating mutations in the EGFR intracellular domain are however, related to the clinical response to EGFR TKIs, gefitinib and erlotinib, in patients with advanced NSCLC. Other genomic alterations of EGFR, even in other malignancies, have been identified through various preclinical studies, although they have not yet been applied in clinical practice. Further clinical investigations are needed to clarify the relationship between genomic changes and therapeutic efficacy.

\section{ACKNOWLEDGEMENT}

Giuseppe Bronte and Marianna Terrasi contributed equally to this work

\section{REFERENCES}

1. J. Mendelsohn and J. Baselga: The EGF receptor family as targets for cancer therapy. Oncogene, 19(56), 6550-65 (2000)

2. A. W. Burgess, H. S. Cho, C. Eigenbrot, K. M. Ferguson, T. P. Garrett, D. J. Leahy, M. A. Lemmon, M. X. Sliwkowski, C. W. Ward and S. Yokoyama: An open-andshut case? Recent insights into the activation of EGF/ErbB receptors. Mol Cell, 12(3), 541-52 (2003)

3. L. A. Bazley and W. J. Gullick: The epidermal growth factor receptor family. Endocr Relat Cancer, 12 Suppl 1, S17-27 (2005)

4. A. Kumar, E. T. Petri, B. Halmos and T. J. Boggon: Structure and clinical relevance of the epidermal growth 
factor receptor in human cancer. J Clin Oncol, 26(10), 1742-51 (2008)

5. D. S. Salomon, R. Brandt, F. Ciardiello and N. Normanno: Epidermal growth factor-related peptides and their receptors in human malignancies. Crit Rev Oncol Hematol, 19(3), 183-232 (1995)

6. R. I. Nicholson, J. M. Gee and M. E. Harper: EGFR and cancer prognosis. Eur J Cancer, 37 Suppl 4, S9-15 (2001)

7. J. P. Spano, G. Milano, S. Vignot and D. Khayat: Potential predictive markers of response to EGFR-targeted therapies in colorectal cancer. Crit Rev Oncol Hematol, 66(1), 21-30 (2008)

8. D. Cunningham, Y. Humblet, S. Siena, D. Khayat, H. Bleiberg, A. Santoro, D. Bets, M. Mueser, A. Harstrick, C. Verslype, I. Chau and E. Van Cutsem: Cetuximab monotherapy and cetuximab plus irinotecan in irinotecanrefractory metastatic colorectal cancer. $N$ Engl $J$ Med, 351(4), 337-45 (2004)

9. H. J. Lenz, E. Van Cutsem, S. Khambata-Ford, R. J. Mayer, P. Gold, P. Stella, B. Mirtsching, A. L. Cohn, A. W. Pippas, N. Azarnia, Z. Tsuchihashi, D. J. Mauro and E. K. Rowinsky: Multicenter phase II and translational study of cetuximab in metastatic colorectal carcinoma refractory to irinotecan, oxaliplatin, and fluoropyrimidines. $J$ Clin Oncol, 24(30), 4914-21 (2006)

10. L. B. Saltz, N. J. Meropol, P. J. Loehrer, Sr., M. N. Needle, J. Kopit and R. J. Mayer: Phase II trial of cetuximab in patients with refractory colorectal cancer that expresses the epidermal growth factor receptor. $J$ Clin Oncol, 22(7), 1201-8 (2004)

11. K. Y. Chung, J. Shia, N. E. Kemeny, M. Shah, G. K. Schwartz, A. Tse, A. Hamilton, D. Pan, D. Schrag, L. Schwartz, D. S. Klimstra, D. Fridman, D. P. Kelsen and L. B. Saltz: Cetuximab shows activity in colorectal cancer patients with tumors that do not express the epidermal growth factor receptor by immunohistochemistry. J Clin Oncol, 23(9), 1803-10 (2005)

12. J. Berlin, J. Posey, S. Tchekmedyian, E. Hu, D. Chan, I. Malik, L. Yang, R. G. Amado and J. R. Hecht: Panitumumab with irinotecan/leucovorin/5-fluorouracil for first-line treatment of metastatic colorectal cancer. Clin Colorectal Cancer, 6(6), 427-32 (2007)

13. J. R. Hecht, E. Mitchell, M. A. Neubauer, H. A. Burris, 3rd, P. Swanson, T. Lopez, G. Buchanan, M. Reiner, J. Gansert and J. Berlin: Lack of correlation between epidermal growth factor receptor status and response to Panitumumab monotherapy in metastatic colorectal cancer. Clin Cancer Res, 16(7), 2205-13 (2010)

14. M. Agulnik, G. da Cunha Santos, D. Hedley, T. Nicklee, P. P. Dos Reis, J. Ho, G. R. Pond, H. Chen, S. Chen, Y. Shyr, E. Winquist, D. Soulieres, E. X. Chen, J. A. Squire, P. Marrano, S. Kamel-Reid, J. Dancey, L. L. Siu and M. S. Tsao: Predictive and pharmacodynamic biomarker studies in tumor and skin tissue samples of patients with recurrent or metastatic squamous cell carcinoma of the head and neck treated with erlotinib. $J$ Clin Oncol, 25(16), 2184-90 (2007)

15. F. Cappuzzo: Predictive factors for response and for resistance to tyrosine kinase inhibitor therapy in lung cancer. J Thorac Oncol, 2(5 Suppl), S12-4 (2007)

16. J. Y. Douillard, F. A. Shepherd, V. Hirsh, T. Mok, M. A. Socinski, R. Gervais, M. L. Liao, H. Bischoff, M. Reck, M. V. Sellers, C. L. Watkins, G. Speake, A. A. Armour and E. S. Kim: Molecular predictors of outcome with gefitinib and docetaxel in previously treated nonsmall-cell lung cancer: data from the randomized phase III INTEREST trial. J Clin Oncol, 28(5), 744-52 (2010)

17. D. A. Haas-Kogan, M. D. Prados, K. R. Lamborn, T. Tihan, M. S. Berger and D. Stokoe: Biomarkers to predict response to epidermal growth factor receptor inhibitors. Cell Cycle, 4(10), 1369-72 (2005)

18. S. W. Han, T. Y. Kim, P. G. Hwang, S. Jeong, J. Kim, I. S. Choi, D. Y. Oh, J. H. Kim, D. W. Kim, D. H. Chung, S. A. Im, Y. T. Kim, J. S. Lee, D. S. Heo, Y. J. Bang and N. K. Kim: Predictive and prognostic impact of epidermal growth factor receptor mutation in nonsmall-cell lung cancer patients treated with gefitinib. $J$ Clin Oncol, 23(11), 2493-501 (2005)

19. R. S. Herbst, D. Prager, R. Hermann, L. Fehrenbacher, B. E. Johnson, A. Sandler, M. G. Kris, H. T. Tran, P. Klein, X. Li, D. Ramies, D. H. Johnson and V. A. Miller: TRIBUTE: a phase III trial of erlotinib hydrochloride (OSI-774) combined with carboplatin and paclitaxel chemotherapy in advanced non-small-cell lung cancer. J Clin Oncol, 23(25), 5892-9 (2005)

20. S. Kakiuchi, Y. Daigo, N. Ishikawa, C. Furukawa, T. Tsunoda, S. Yano, K. Nakagawa, T. Tsuruo, N. Kohno, M. Fukuoka, S. Sone and Y. Nakamura: Prediction of sensitivity of advanced non-small cell lung cancers to gefitinib (Iressa, ZD1839). Hum Mol Genet, 13(24), 3029-43 (2004)

21. M. Loprevite, M. Tiseo, M. Chiaramondia, M. Capelletti, C. Bozzetti, B. Bortesi, N. Naldi, R. Nizzoli, P. Dadati, A. Kunkl, D. Zennaro, C. Lagrasta, N. Campanini, E. Spiritelli, R. Camisa, F. Grossi, G. Rindi, V. Franciosi and A. Ardizzoni: Buccal mucosa cells as in vivo model to evaluate gefitinib activity in patients with advanced non small cell lung cancer. Clin Cancer Res, 13(21), 6518-26 (2007)

22. I. K. Mellinghoff, M. Y. Wang, I. Vivanco, D. A. HaasKogan, S. Zhu, E. Q. Dia, K. V. Lu, K. Yoshimoto, J. H. Huang, D. J. Chute, B. L. Riggs, S. Horvath, L. M. Liau, W. K. Cavenee, P. N. Rao, R. Beroukhim, T. C. Peck, J. C. Lee, W. R. Sellers, D. Stokoe, M. Prados, T. F. Cloughesy, C. L. Sawyers and P. S. Mischel: Molecular determinants 
of the response of glioblastomas to EGFR kinase inhibitors. N Engl J Med, 353(19), 2012-24 (2005)

23. M. J. Moore, D. Goldstein, J. Hamm, A. Figer, J. R. Hecht, S. Gallinger, H. J. Au, P. Murawa, D. Walde, R. A. Wolff, D. Campos, R. Lim, K. Ding, G. Clark, T. Voskoglou-Nomikos, M. Ptasynski and W. Parulekar: Erlotinib plus gemcitabine compared with gemcitabine alone in patients with advanced pancreatic cancer: a phase III trial of the National Cancer Institute of Canada Clinical Trials Group. J Clin Oncol, 25(15), 1960-6 (2007)

24. R. Perez-Soler, A. Chachoua, L. A. Hammond, E. K. Rowinsky, M. Huberman, D. Karp, J. Rigas, G. M. Clark, P. Santabarbara and P. Bonomi: Determinants of tumor response and survival with erlotinib in patients with non-small-cell lung cancer. J Clin Oncol, 22(16), 3238-47 (2004)

25. J. N. Rich, B. K. Rasheed and H. Yan: EGFR mutations and sensitivity to gefitinib. $N$ Engl $J$ Med, 351(12), 1260-1; author reply 1260-1 (2004)

26. M. S. Tsao, A. Sakurada, J. C. Cutz, C. Q. Zhu, S. KamelReid, J. Squire, I. Lorimer, T. Zhang, N. Liu, M. Daneshmand, P. Marrano, G. da Cunha Santos, A. Lagarde, F. Richardson, L. Seymour, M. Whitehead, K. Ding, J. Pater and F. A. Shepherd: Erlotinib in lung cancer - molecular and clinical predictors of outcome. N Engl J Med, 353(2), 133-44 (2005)

27. F. R. Hirsch, M. Varella-Garcia, P. A. Bunn, Jr., W. A. Franklin, R. Dziadziuszko, N. Thatcher, A. Chang, P. Parikh, J. R. Pereira, T. Ciuleanu, J. von Pawel, C. Watkins, A. Flannery, G. Ellison, E. Donald, L. Knight, D. Parums, N. Botwood and B. Holloway: Molecular predictors of outcome with gefitinib in a phase III placebo-controlled study in advanced non-small-cell lung cancer. J Clin Oncol, 24(31), 5034-42 (2006)

28. L. R. Bailey, M. G. Kris and M. e. a. Wolf: Tumor EGFR membrane staining is not clinically relevant for predicting response in patients receiving gefitinib (Iressa, ZD1939) monotherapy for pretreated advanced non-small-cell lung cancer: IDEAL1 and 2 Proc Am Assoc Cancer, 44, 1362 (abstract LB-170) (2003)

29. J. Shia, D. S. Klimstra, A. R. Li, J. Qin, L. Saltz, J. TeruyaFeldstein, M. Akram, K. Y. Chung, D. Yao, P. B. Paty, W. Gerald and B. Chen: Epidermal growth factor receptor expression and gene amplification in colorectal carcinoma: an immunohistochemical and chromogenic in situ hybridization study. Mod Pathol, 18(10), 1350-6 (2005)

30. T. Mitsudomi and Y. Yatabe: Mutations of the epidermal growth factor receptor gene and related genes as determinants of epidermal growth factor receptor tyrosine kinase inhibitors sensitivity in lung cancer. Cancer Sci, 98(12), 1817-24 (2007)

31. W. Pao, V. Miller, M. Zakowski, J. Doherty, K. Politi, I. Sarkaria, B. Singh, R. Heelan, V. Rusch, L. Fulton, E. Mardis, D. Kupfer, R. Wilson, M. Kris and H. Varmus: EGF receptor gene mutations are common in lung cancers from "never smokers" and are associated with sensitivity of tumors to gefitinib and erlotinib. Proc Natl Acad Sci U S A, 101(36), 13306-11 (2004)

32. T. J. Lynch, D. W. Bell, R. Sordella, S. Gurubhagavatula, R. A. Okimoto, B. W. Brannigan, P. L. Harris, S. M. Haserlat, J. G. Supko, F. G. Haluska, D. N. Louis, D. C. Christiani, J. Settleman and D. A. Haber: Activating mutations in the epidermal growth factor receptor underlying responsiveness of non-small-cell lung cancer to gefitinib. N Engl J Med, 350(21), 2129-39 (2004)

33. J. G. Paez, P. A. Janne, J. C. Lee, S. Tracy, H. Greulich, S. Gabriel, P. Herman, F. J. Kaye, N. Lindeman, T. J. Boggon, K. Naoki, H. Sasaki, Y. Fujii, M. J. Eck, W. R. Sellers, B. E. Johnson and M. Meyerson: EGFR mutations in lung cancer: correlation with clinical response to gefitinib therapy. Science, 304(5676), 1497-500 (2004)

34. K. D. Carey, A. J. Garton, M. S. Romero, J. Kahler, S. Thomson, S. Ross, F. Park, J. D. Haley, N. Gibson and M. X. Sliwkowski: Kinetic analysis of epidermal growth factor receptor somatic mutant proteins shows increased sensitivity to the epidermal growth factor receptor tyrosine kinase inhibitor, erlotinib. Cancer Res, 66(16), 8163-71 (2006)

35. C. H. Yun, T. J. Boggon, Y. Li, M. S. Woo, H. Greulich, M. Meyerson and M. J. Eck: Structures of lung cancer-derived EGFR mutants and inhibitor complexes: mechanism of activation and insights into differential inhibitor sensitivity. Cancer Cell, 11(3), 217-27 (2007)

36. D. M. Jackman, B. Y. Yeap, N. I. Lindeman, P. Fidias, M. S. Rabin, J. Temel, A. T. Skarin, M. Meyerson, A. J. Holmes, A. M. Borras, B. Freidlin, P. A. Ostler, J. Lucca, T. J. Lynch, B. E. Johnson and P. A. Janne: Phase II clinical trial of chemotherapy-naive patients $>$ or $=70$ years of age treated with erlotinib for advanced non-small-cell lung cancer. J Clin Oncol, 25(7), 760-6 (2007)

37. G. J. Riely, K. A. Politi, V. A. Miller and W. Pao: Update on epidermal growth factor receptor mutations in non-small cell lung cancer. Clin Cancer Res, 12(24), 723241 (2006)

38. R. Rosell, T. Moran, C. Queralt, R. Porta, F. Cardenal, C. Camps, M. Majem, G. Lopez-Vivanco, D. Isla, M. Provencio, A. Insa, B. Massuti, J. L. Gonzalez-Larriba, L. Paz-Ares, I. Bover, R. Garcia-Campelo, M. A. Moreno, S. Catot, C. Rolfo, N. Reguart, R. Palmero, J. M. Sanchez, R. Bastus, C. Mayo, J. Bertran-Alamillo, M. A. Molina, J. J. Sanchez and M. Taron: Screening for epidermal growth factor receptor mutations in lung cancer. $N$ Engl J Med, 361(10), 958-67 (2009)

39. J. M. Sun, Y. W. Won, S. T. Kim, J. H. Kim, Y. L. Choi, J. Lee, Y. H. Park, J. S. Ahn, K. Park and M. J. Ahn: The different efficacy of gefitinib or erlotinib according to epidermal growth factor receptor exon 19 and exon 21 mutations in Korean non-small cell lung cancer patients. $J$ Cancer Res Clin Oncol (2010) 
40. D. M. Jackman, V. A. Miller, L. A. Cioffredi, B. Y. Yeap, P. A. Janne, G. J. Riely, M. G. Ruiz, G. Giaccone, L. V. Sequist and B. E. Johnson: Impact of epidermal growth factor receptor and KRAS mutations on clinical outcomes in previously untreated non-small cell lung cancer patients: results of an online tumor registry of clinical trials. Clin Cancer Res, 15(16), 5267-73 (2009)

41. E. S. Kim, V. Hirsh, T. Mok, M. A. Socinski, R. Gervais, Y. L. Wu, L. Y. Li, C. L. Watkins, M. V. Sellers, E. S. Lowe, Y. Sun, M. L. Liao, K. Osterlind, M. Reck, A. A. Armour, F. A. Shepherd, S. M. Lippman and J. Y. Douillard: Gefitinib versus docetaxel in previously treated non-small-cell lung cancer (INTEREST): a randomised phase III trial. Lancet, 372(9652), 1809-18 (2008)

42. T. S. Mok, Y. L. Wu, S. Thongprasert, C. H. Yang, D. T. Chu, N. Saijo, P. Sunpaweravong, B. Han, B. Margono, Y. Ichinose, Y. Nishiwaki, Y. Ohe, J. J. Yang, B. Chewaskulyong, H. Jiang, E. L. Duffield, C. L. Watkins, A. A. Armour and M. Fukuoka: Gefitinib or carboplatinpaclitaxel in pulmonary adenocarcinoma. $N$ Engl $\mathrm{J} \mathrm{Med,}$ 361(10), 947-57 (2009)

43. S. Kobayashi, T. J. Boggon, T. Dayaram, P. A. Janne, O. Kocher, M. Meyerson, B. E. Johnson, M. J. Eck, D. G. Tenen and B. Halmos: EGFR mutation and resistance of non-small-cell lung cancer to gefitinib. $N$ Engl J Med, 352(8), 786-92 (2005)

44. W. Pao, V. A. Miller, K. A. Politi, G. J. Riely, R. Somwar, M. F. Zakowski, M. G. Kris and H. Varmus: Acquired resistance of lung adenocarcinomas to gefitinib or erlotinib is associated with a second mutation in the EGFR kinase domain. PLoS Med, 2(3), e73 (2005)

45. S. Maheswaran, L. V. Sequist, S. Nagrath, L. Ulkus, B. Brannigan, C. V. Collura, E. Inserra, S. Diederichs, A. J. Iafrate, D. W. Bell, S. Digumarthy, A. Muzikansky, D. Irimia, J. Settleman, R. G. Tompkins, T. J. Lynch, M. Toner and D. A. Haber: Detection of mutations in EGFR in circulating lung-cancer cells. $N$ Engl J Med, 359(4), 366-77 (2008)

46. E. L. Kwak, R. Sordella, D. W. Bell, N. GodinHeymann, R. A. Okimoto, B. W. Brannigan, P. L. Harris, D. R. Driscoll, P. Fidias, T. J. Lynch, S. K. Rabindran, J. P. McGinnis, A. Wissner, S. V. Sharma, K. J. Isselbacher, J. Settleman and D. A. Haber: Irreversible inhibitors of the EGF receptor may circumvent acquired resistance to gefitinib. Proc Natl Acad Sci U S A, 102(21), 7665-70 (2005)

47. L. V. Sequist: Second-generation epidermal growth factor receptor tyrosine kinase inhibitors in non-small cell lung cancer. Oncologist, 12(3), 325-30 (2007)

48. C. H. Yun, K. E. Mengwasser, A. V. Toms, M. S. Woo, H. Greulich, K. K. Wong, M. Meyerson and M. J. Eck: The T790M mutation in EGFR kinase causes drug resistance by increasing the affinity for ATP. Proc Natl Acad Sci U S A, 105(6), 2070-5 (2008)
49. N. Godin-Heymann, I. Bryant, M. N. Rivera, L. Ulkus, D. W. Bell, D. J. Riese, 2nd, J. Settleman and D. A. Haber: Oncogenic activity of epidermal growth factor receptor kinase mutant alleles is enhanced by the T790M drug resistance mutation. Cancer Res, 67(15), 7319-26 (2007)

50. L. Regales, M. N. Balak, Y. Gong, K. Politi, A. Sawai, C. Le, J. A. Koutcher, D. B. Solit, N. Rosen, M. F. Zakowski and W. Pao: Development of new mouse lung tumor models expressing EGFR T790M mutants associated with clinical resistance to kinase inhibitors. PLoS One, 2(8), e810 (2007)

51. D. Li, T. Shimamura, H. Ji, L. Chen, H. J. Haringsma, K. McNamara, M. C. Liang, S. A. Perera, S. Zaghlul, C. L. Borgman, S. Kubo, M. Takahashi, Y. Sun, L. R. Chirieac, R. F. Padera, N. I. Lindeman, P. A. Janne, R. K. Thomas, M. L. Meyerson, M. J. Eck, J. A. Engelman, G. I. Shapiro and $\mathrm{K}$. K. Wong: Bronchial and peripheral murine lung carcinomas induced by T790M-L858R mutant EGFR respond to HKI-272 and rapamycin combination therapy. Cancer Cell, 12(1), 81-93 (2007)

52. W. Pao and V. A. Miller: Epidermal growth factor receptor mutations, small-molecule kinase inhibitors, and non-small-cell lung cancer: current knowledge and future directions. J Clin Oncol, 23(11), 2556-68 (2005)

53. H. Kimura, Y. Fujiwara, T. Sone, H. Kunitoh, T. Tamura, K. Kasahara and K. Nishio: High sensitivity detection of epidermal growth factor receptor mutations in the pleural effusion of non-small cell lung cancer patients. Cancer Sci, 97(7), 642-8 (2006)

54. T. D. Barber, B. Vogelstein, K. W. Kinzler and V. E. Velculescu: Somatic mutations of EGFR in colorectal cancers and glioblastomas. $N$ Engl J Med, 351(27), 2883 (2004)

55. M. Moroni, S. Veronese, S. Benvenuti, G. Marrapese, A. Sartore-Bianchi, F. Di Nicolantonio, M. Gambacorta, S. Siena and A. Bardelli: Gene copy number for epidermal growth factor receptor (EGFR) and clinical response to antiEGFR treatment in colorectal cancer: a cohort study. Lancet Oncol, 6(5), 279-86 (2005)

56. S. Ogino, J. A. Meyerhardt, M. Cantor, M. Brahmandam, J. W. Clark, C. Namgyal, T. Kawasaki, K. Kinsella, A. L. Michelini, P. C. Enzinger, M. H. Kulke, D. P. Ryan, M. Loda and C. S. Fuchs: Molecular alterations in tumors and response to combination chemotherapy with gefitinib for advanced colorectal cancer. Clin Cancer Res, 11(18), 6650-6 (2005)

57. B. R. Voldborg, L. Damstrup, M. Spang-Thomsen and H. S. Poulsen: Epidermal growth factor receptor (EGFR) and EGFR mutations, function and possible role in clinical trials. Ann Oncol, 8(12), 1197-206 (1997)

58. I. E. Garcia de Palazzo, G. P. Adams, P. Sundareshan, A. J. Wong, J. R. Testa, D. D. Bigner and L. M. Weiner: Expression of mutated epidermal growth factor receptor by 
non-small cell lung carcinomas. Cancer Res, 53(14), 321720 (1993)

59. P. H. Huang, W. K. Cavenee, F. B. Furnari and F. M. White: Uncovering therapeutic targets for glioblastoma: a systems biology approach. Cell Cycle, 6(22), 2750-4 (2007)

60. I. A. Lorimer: Mutant epidermal growth factor receptors as targets for cancer therapy. Curr Cancer Drug Targets, 2(2), 91-102 (2002)

61. A. M. Sonabend, K. Dana and M. S. Lesniak: Targeting epidermal growth factor receptor variant III: a novel strategy for the therapy of malignant glioma. Expert Rev Anticancer Ther, 7(12 Suppl), S45-50 (2007)

62. F. B. Furnari, T. Fenton, R. M. Bachoo, A. Mukasa, J. M. Stommel, A. Stegh, W. C. Hahn, K. L. Ligon, D. N. Louis, C. Brennan, L. Chin, R. A. DePinho and W. K. Cavenee: Malignant astrocytic glioma: genetics, biology, and paths to treatment. Genes Dev, 21(21), 2683-710 (2007)

63. N. Sugawa, A. J. Ekstrand, C. D. James and V. P. Collins: Identical splicing of aberrant epidermal growth factor receptor transcripts from amplified rearranged genes in human glioblastomas. Proc Natl Acad Sci U S A, 87(21), 8602-6 (1990)

64. C. A. Learn, T. L. Hartzell, C. J. Wikstrand, G. E. Archer, J. N. Rich, A. H. Friedman, H. S. Friedman, D. D. Bigner and J. H. Sampson: Resistance to tyrosine kinase inhibition by mutant epidermal growth factor receptor variant III contributes to the neoplastic phenotype of glioblastoma multiforme. Clin Cancer Res, 10(9), 3216-24 (2004)

65. H. Ji, X. Zhao, Y. Yuza, T. Shimamura, D. Li, A. Protopopov, B. L. Jung, K. McNamara, H. Xia, K. A. Glatt, R. K. Thomas, H. Sasaki, J. W. Horner, M. Eck, A. Mitchell, Y. Sun, R. Al-Hashem, R. T. Bronson, S. K. Rabindran, C. M. Discafani, E. Maher, G. I. Shapiro, M. Meyerson and K. K. Wong: Epidermal growth factor receptor variant III mutations in lung tumorigenesis and sensitivity to tyrosine kinase inhibitors. Proc Natl Acad Sci U S A, 103(20), 7817-22 (2006)

66. M. Azuma, K. D. Danenberg, S. Iqbal, A. ElKhoueiry, P. V. Danenberg, W. Fazzone, R. D. Ladner and H. J. Lenz: EGFR and EGFR VIII gene expression in metastatic colorectal cancer (mCRC). In: Gastrointestinal Cancers Symposium. (2006)

67. V. Martin, L. Mazzucchelli and M. Frattini: An overview of the epidermal growth factor receptor fluorescence in situ hybridisation challenge in tumour pathology. J Clin Pathol, 62(4), 314-24 (2009)

68. J. J. Carlson, L. P. Garrison, S. D. Ramsey and D. L. Veenstra: Epidermal growth factor receptor genomic variation in NSCLC patients receiving tyrosine kinase inhibitor therapy: a systematic review and meta-analysis. $J$ Cancer Res Clin Oncol, 135(11), 1483-93 (2009)

69. F. Cappuzzo, M. Varella-Garcia, H. Shigematsu, I. Domenichini, S. Bartolini, G. L. Ceresoli, E. Rossi, V. Ludovini, V. Gregorc, L. Toschi, W. A. Franklin, L. Crino, A. F. Gazdar, P. A. Bunn, Jr. and F. R. Hirsch: Increased HER2 gene copy number is associated with response to gefitinib therapy in epidermal growth factor receptorpositive non-small-cell lung cancer patients. $J$ Clin Oncol, 23(22), 5007-18 (2005)

70. H. Sasaki, K. Endo, K. Okuda, O. Kawano, N. Kitahara, H. Tanaka, A. Matsumura, K. Iuchi, M. Takada, M. Kawahara, T. Kawaguchi, H. Yukiue, T. Yokoyama, M. Yano and Y. Fujii: Epidermal growth factor receptor gene amplification and gefitinib sensitivity in patients with recurrent lung cancer. J Cancer Res Clin Oncol, 134(5), 569-77 (2008)

71. M. Varella-Garcia, T. Mitsudomi, Y. Yatabe, T. Kosaka, E. Nakajima, A. C. Xavier, M. Skokan, C. Zeng, W. A. Franklin, P. A. Bunn, Jr. and F. R. Hirsch: EGFR and HER2 genomic gain in recurrent non-small cell lung cancer after surgery: impact on outcome to treatment with gefitinib and association with EGFR and KRAS mutations in a Japanese cohort. J Thorac Oncol, 4(3), 318-25 (2009)

72. J. Amann, S. Kalyankrishna, P. P. Massion, J. E. Ohm, L. Girard, H. Shigematsu, M. Peyton, D. Juroske, Y. Huang, J. Stuart Salmon, Y. H. Kim, J. R. Pollack, K. Yanagisawa, A. Gazdar, J. D. Minna, J. M. Kurie and D. P. Carbone: Aberrant epidermal growth factor receptor signaling and enhanced sensitivity to EGFR inhibitors in lung cancer. Cancer Res, 65(1), 226-35 (2005)

73. R. Morinaga, I. Okamoto, Y. Fujita, T. Arao, M. Sekijima, K. Nishio, H. Ito, M. Fukuoka, J. Kadota and K. Nakagawa: Association of epidermal growth factor receptor (EGFR) gene mutations with EGFR amplification in advanced non-small cell lung cancer. Cancer Sci, 99(12), 2455-60 (2008)

74. H. Sasaki, S. Shimizu, K. Okuda, O. Kawano, H. Yukiue, M. Yano and Y. Fujii: Epidermal growth factor receptor gene amplification in surgical resected Japanese lung cancer. Lung Cancer, 64(3), 295-300 (2009)

75. T. Takano and Y. Ohe: Erlotinib in lung cancer. $N$ Engl $J$ Med, 353(16), 1739-41; author reply 1739-41 (2005)

76. M. Taron, Y. Ichinose, R. Rosell, T. Mok, B. Massuti, L. Zamora, J. L. Mate, C. Manegold, M. Ono, C. Queralt, T. Jahan, J. J. Sanchez, M. Sanchez-Ronco, V. Hsue, D. Jablons, J. M. Sanchez and T. Moran: Activating mutations in the tyrosine kinase domain of the epidermal growth factor receptor are associated with improved survival in gefitinib-treated chemorefractory lung adenocarcinomas. Clin Cancer Res, 11(16), 5878-85 (2005)

77. S. Tracy, T. Mukohara, M. Hansen, M. Meyerson, B. E. Johnson and P. A. Janne: Gefitinib induces apoptosis in the 
EGFRL858R non-small-cell lung cancer cell line H3255. Cancer Res, 64(20), 7241-4 (2004)

78. T. Sauer, M. G. Guren, T. Noren and S. Dueland: Demonstration of EGFR gene copy loss in colorectal carcinomas by fluorescence in situ hybridization (FISH): a surrogate marker for sensitivity to specific anti-EGFR therapy? Histopathology, 47(6), 560-4 (2005)

79. A. Lievre, J. B. Bachet, D. Le Corre, V. Boige, B. Landi, J. F. Emile, J. F. Cote, G. Tomasic, C. Penna, M. Ducreux, P. Rougier, F. Penault-Llorca and P. LaurentPuig: KRAS mutation status is predictive of response to cetuximab therapy in colorectal cancer. Cancer Res, 66(8), 3992-5 (2006)

80. A. Sartore-Bianchi, M. Moroni, S. Veronese, C. Carnaghi, E. Bajetta, G. Luppi, A. Sobrero, C. Barone, S. Cascinu, G. Colucci, E. Cortesi, M. Nichelatti, M. Gambacorta and S. Siena: Epidermal growth factor receptor gene copy number and clinical outcome of metastatic colorectal cancer treated with panitumumab. J Clin Oncol, 25(22), 3238-45 (2007)

81. S. Khambata-Ford, C. R. Garrett, N. J. Meropol, M. Basik, C. T. Harbison, S. Wu, T. W. Wong, X. Huang, C. H. Takimoto, A. K. Godwin, B. R. Tan, S. S. Krishnamurthi, H. A. Burris, 3rd, E. A. Poplin, M. Hidalgo, J. Baselga, E. A. Clark and D. J. Mauro: Expression of epiregulin and amphiregulin and K-ras mutation status predict disease control in metastatic colorectal cancer patients treated with cetuximab. J Clin Oncol, 25(22), 3230-7 (2007)

Key Words: EGFR, Monoclonal Antibodies, Tyrosine Kinase Inhibitors, Review

Send correspondence to: Antonio Russo, Department of Surgical and Oncological Sciences, Section of Medical Oncology, Universita di Palermo, Palermo, Italy, Via del Vespro 127 - 90127 Palermo, Italy, Tel: 39-091-6552500, Fax: 39-091-6554529, E-mail: lab-oncobiologia@usa.net 